\title{
UNIA ENERGETYCZNA - KONCEPCJA, REALIZACJA, STAN OBECNY
}

\author{
Ewelina Paszkiewicz \\ Uniwersytet Jana Kochanowskiego w Kielcach \\ Wydział Prawa i Nauk Społecznych \\ ORCID ID: https://orcid.org/0000-0003-2419-3460 \\ e-mail: ewel.paszkiewicz@gmail.com
}

\begin{abstract}
Streszczenie: Celem artykułu jest analiza unii energetycznej - projektu integracji państw członkowskich w sektorze energii ogłoszony przez Komisję Europejską w 2015 r. W artykule zostały przeanalizowane założenia unii energetycznej wraz z postępami jej realizacji. Projekt unii energetycznej jest pierwszą inicjatywą, która pozwoli na integrację sektora energetycznego.
\end{abstract}

Słowa kluczowe: unia energetyczna; polityka energetyczna; integracja sektora energetycznego; polityka energetyczno-klimatyczna

\section{WSTĘP}

Ciągle postępująca integracja europejska w ciągu ostatnich kilku lat zauważalna jest także w sektorze energetycznym, tak długo pozostającym jedynie w gestii państw członkowskich. Bezpośredni wpływ na zmianę postrzegania bezpieczeństwa energetycznego miały kryzysy gazowe z roku 2006 i 2009 [Trubalska 2017], w których to Rosja wstrzymała przepływ gazu na Ukrainę, tym samym wstrzymując dostawy gazu do państw Unii Europejskiej. Te wydarzenia, ukazujące słabości w systemach energetycznych państw członkowskich sprowokowały dyskusje o zwiększeniu bezpieczeństwa energetycznego w ramach Unii Europejskiej oraz dyskusje na temat utworzenia mechanizmów reagowania kryzysowego. Garrison podczas przeprowadzania analizy pojęcia „kryzysu energetycznego” podkreślił, że w zwiększaniu bezpieczeństwa energetycznego szczególne znaczenie ma długoterminowe planowanie polityki surowcowej, w której ważne jest uwzględnienie odpowiedniego ryzyka przyczyniającego się do destabilizacji dostaw [Garrison 1981]

Pierwsze koncepcje integracyjne w sektorze energii zostały zaproponowane przez polski rząd Marcinkiewicza w $2006 \mathrm{r}$. a polegały w znacznej mierze na stwo- 
rzeniu mechanizmu solidarnościowego i zasadzie ,jeden za wszystkich, wszyscy za jednego" [Ruszel 2015]. Koncepcja ta jednak nie znalazła poparcia. Kolejne koncepcje zostały zaproponowane w 2010 roku a ich pomysłodawcami byli Jerzy Buzek były przewodniczący Parlamentu Europejskiego oraz Jacques Delors - były przewodniczący Komisji Europejskiej. Koncepcja ta bazowała przede wszystkim na wspólnych zakupach gazu i solidarności w kontaktach z państwami trzecimi [Kancelaria Senatu, 2010]. Koncepcja zakładała integrację tylko tych państw, które w danym momencie są na to gotowe. Reszta państw dołączałaby w swoim tempie. Koncepcja na kilka lat ucichła, jednak po kolejnych kryzach w 2014 r. związanymi z aneksją Krymu przez Federację Rosyjską pomysł aby razem zwiększyć bezpieczeństwo energetyczne powrócił. Aktywnym kontynuatorem idei zacieśnienia integracji europejskiej w sektorze energetycznym był polski premier Donald Tusk. W dokumencie przedstawionym w kwietniu 2014 roku „Mapa drogowa na rzecz Unii Energetycznej dla Europy, Non-paper adresujący wyzwania zależności energetycznej UE” zamieścił sześć filarów na jakich powinna opierać się unia energetyczna. Były to: infrastruktura energetyczna - głównie przesyłowa mająca na celu usuniecie wysp energetycznych oraz tzw. wąskich gardel, utworzenie mechanizmów solidarnościowych, zwiększenie siły przetargowej państw członkowskich i UE wobec dostawców zewnętrznych, rozwój rodzimych źródeł energii w UE, dywersyfikacja dostaw energii do UE - w szczególności w odniesieniu do ropy i gazu oraz wzmocnienie Wspólnoty Energetycznej. Niektóre z zaproponowanych kierunków działań wprost kłóciły się z założeniami prowadzonej przez Unię Europejską polityki energetyczno-klimatycznej. Jednakże koncepcja zyskała aprobatę i rozgłos a co ważniejsze - rozpoczęła poważne dyskusje nad kształtem przyszłej unii energetycznej. Wynikiem było ogłoszenie przez Komisję Europejską w lutym 2015 r. „Strategii ramowej na rzecz stabilnej unii energetycznej opartej na przyszłościowej polityce w dziedzinie klimatu" [Strategia ramowa ..., 2015].

Celem artykułu jest przedstawienie koncepcji unii energetycznej oraz etapów jej realizacji a także odpowiedź na pytanie: czy faktycznie unia energetyczna jest już rzeczywistością tak jak ogłosiła to w swoim komunikacie pn. „Czwarte sprawozdanie na temat stanu unii energetycznej” [Czwarte sprawozdanie.., 2019] Komisja Europejska?

Warto podkreślić, że aktualnie koncepcja unii energetycznej nie doczekała się zbyt wielu publikacji zwartych w literaturze polskiej. Do najważniejszych pozycji należy zaliczyć książkę A. Łada, M. Skłodowska, M. Szczepanik, Ł. Wenerski Unia energetyczna z perspektywy Francji, Niemiec, Polski i Wielkiej Brytanii (Warszawa, 2015) oraz książkę napisaną pod red. G. Wojtkowska-Łodej Europejska unia energetyczna. Wybrane zagadnienia (Warszawa, 2016). Niemniej jednak pozycje te są nieaktualne na dzień dzisiejszy. Tematyka unii energetycznej częściej podejmowana jest w postaci artykułów naukowych i publicystycznych a także na stronach internetowych. Warto w tym miejscu wymienić artykuł Trubalska J., $W$ kierunku unii energetycznej. Nowa koncepcja bezpieczeństwa energetycznego w Unii Europejskiej [Zeszyty Naukowe Instytutu Gospodarki Surowcami Mineralnymi i Energią 
Polskiej Akademii Nauk 2017] oraz A. Gawlikowska-Fyk Zarzadzanie uniq energetyczna - transfer kompetencji do UE [Biuletyn PISM 2018].

$\mathrm{W}$ artykule zastosowana będzie metoda analizy stanu literatury, dostępnych publikacji i dokumentów oraz analiza czynnikowa. Biorąc pod uwagę szeroki zakres tematyczny unii energetycznej autorka wybrała jedynie najważniejsze jej zdaniem obszary działalności w poszczególnych filarach, które odnoszą się bezpośrednio do idei unii energetycznej i jej założeń. W „Strategii ramowej” Komisja Europejska zaproponowała utworzenie unii energetycznej opierającej się na wzajemnie uzupełniających się filarach. Są to: bezpieczeństwo energetyczne, solidarność i zaufanie; w pełni zintegrowany europejski rynek energii; efektywność energetyczna przyczyniająca się do ograniczenia popytu; dekarbonizacja gospodarki oraz badania naukowe, innowacje i konkurencyjność. Z poszczególnych filarów wybrane zostały te działania, które mają największe znaczenie dla koncepcji unii energetycznej a w ich obszarze zostało dokonanych najwięcej postępów. Praca obejmuje stan prawny na wrzesień 2020 roku.

\section{WZMOCNIENIE BEZPIECZEŃSTWA ENERGETYCZNEGO POPRZEZ PROJEKTY INFRASTRUKTURALNE ORAZ BUDOWĘ WSPÓLNEGO RYNKU ENERGII}

W zakresie pierwszego filaru Komisja zaproponowała przede wszystkim działanie mające na celu wzmocnienie dywersyfikacji dostaw zarówno w zakresie źródeł energii jak również tras dostaw oraz dostawców oraz wzmocnienie współpracy na rzecz bezpieczeństwa dostaw. W zapewnianiu bezpieczeństwa energetycznego Unii Europejskiej najważniejszym czynnikiem jest zdywersyfikowanie dostaw energii. Dywersyfikacja wzmocniłaby bezpieczeństwo dostaw oraz zmniejszyłaby podatność państw Unii Europejskiej na zewnętrzne kryzysy energetyczne [Kucharska 2018]. Dlatego Komisja zaproponowała kilka działań w tym zakresie. Przede wszystkim aby zwiększyć dywersyfikację zarówno tras dostaw jak i dostawców proponuje jak najszybsze ukończenie Południowego Korytarza Gazowego oraz utworzenie centrów obrotu ciekłym gazem (LNG) czyli tzw. hubów gazowych w regionie Europy Północnej, Europy Środkowej i Wschodniej. Jako szansę na zwiększenie bezpieczeństwa energetycznego wskazuje ciągle rozwijający się rynek LNG. Warto zauważyć, że w Strategii ramowej większość działań wymienionych dla zwiększenia dywersyfikacji stanowią działania dotyczące sektora gazowego. Działania podejmowane przez Komisję w tym zakresie należy w większości oceniać pozytywnie. Budowa Południowego Korytarza Gazowego niemal już się zakończyła. Pierwsze dwa odcinki gazociągu tj. Gazociąg Południowokaukaski oraz Transanatolijski zostały już ukończone natomiast odnośnie ostatniego odcinka tj. Gazociągu Transadriatyckiego budowa jest zaawansowana - ocenia się, że pracę są zrealizowane na poziomie około 92\% [CIRE, 2020]. Zakłada się, ze kompletny Południowy Korytarz Gazowy zacznie funkcjonować i przesyłać gaz z końcem 2020 
roku. Pozwoli on na dywersyfikację zarówno tras dostaw (istotne jest, że trasa nie przechodzi przez terytorium Federacji Rosyjskiej) jak też dostawców - gazociągiem początkowo popłynąć ma gaz z Azerbejdżanu jednak są koncepcje aby transportować gaz gazociągiem po dnie Morza Kaspijskiego z Turkmenistanu. Warto jednak podkreślić, że znaczenie ma głównie dla państw korzystających z jego dostaw. Natomiast dla całej UE stanowi jedynie $2 \%$ obecnego zapotrzebowania [Jarosiewicz 2015). Warto jednak podkreślić, że dywersyfikacja kierunków oraz źródeł dostaw gazu ziemnego jest podstawą wzmocnienia bezpieczeństwa energetycznego UE i państw członkowskich z osobna [Flouri, 2015]

Do pozytywnych działań realizujących unię energetyczną w zakresie filaru dotyczącego bezpieczeństwa energetycznego należy także zaliczyć tworzenie centrów obrotu ciekłym gazem. Dzięki wpisywaniu projektów budowy terminali LNG oraz infrastruktury przesyłowej pomiędzy państwami członkowskimi na listy projektów wspólnego zainteresowania (PCI - Projects of Common Interest) inwestycje te udało się ukończyć znacznie szybciej niż w przypadku standardowych procedur. Warto w tym miejscu zaznaczyć, że projekty te korzystały także z unijnego wsparcia finansowego z instrumentu „Łącząc Europę”, który dofinansowywał projekty nawet do $75 \%$.

Odnośnie współpracy na rzecz bezpieczeństwa dostaw Komisja podkreśliła w „Strategii ramowej” rolę wzajemnej współpracy na rzecz zapewnienia wysokiego poziomu bezpieczeństwa energetycznego dla obywateli i przedsiębiorstw w UE. Dlatego Komisja zadeklarowała przedłożenie planów zapobiegawczych i planów działania w sytuacjach wyjątkowych na szczeblu regionalnym i unijnym w celu wprowadzenia wspólnego zarządzania kryzysowego. Istotną rolę w zapewnieniu bezpieczeństwa dostaw pełni mechanizm solidarnościowy, który został ustanowiony w Rozporządzeniu Parlamentu Europejskiego i Rady (UE) 2017/1938 z dnia 25 października 2017 r., dotyczące ustanowienia środków zapewniających bezpieczeństwo dostaw gazu ziemnego (tzw. Rozporządzenie SoS). Rozporządzenie jest częścią pakietu o unii energetycznej i ma na celu ustanowienie procedur zapobiegających wystąpieniu kryzysu dostaw oraz procedur postępowania w przypadku wystąpienia zagrożenia kryzysu dostaw. Rozporządzenie wprowadza ściślejszą współpracę zwłaszcza w grupach państw dzielących ryzyko. Załącznik nr 1 określa grupy ryzyka w podziale na kierunki dostaw tj. grupy ryzyka ze względu na dostawy gazu ze wschodu, z Morza Północnego, z Afryki Północnej oraz z południowego wschodu. Przepisy przewidują obowiązkowe regionalne plany działań zapobiegawczych, plany na wypadek sytuacji nadzwyczajnych oraz regionalne oceny ryzyka, opracowywane wspólnie przez wszystkie państwa członkowskie z tej samej grupy. Dodatkowo, rozporządzenie ustanowiło trzy poziomy kryzysu dostaw gazu: wczesne ostrzeganie, ostrzeganie i sytuacja kryzysowa.

Szczególne znaczenie dla wzmocnienia bezpieczeństwa energetycznego ma także budowa wewnętrznego rynku energii (filar drugi unii energetycznej). Koncepcja unii energetycznej zakłada łączenie rynków poprzez połączenia między- 
systemowe zarówno rynku gazu jak też energii elektrycznej. Proces ten rozpoczął się na długo przed powstaniem koncepcji unii energetycznej [Juszczuk 2015].Aby przyspieszyć proces łączenia rynków konieczne było przyspieszenie budowy infrastruktury przesyłowej. W tym celu powstały cztery grupy regionalne wysokiego szczebla, które dzięki swoim działaniom przyspieszyły budowę wewnętrznego rynku energii. Są to: grupa robocza wysokiego szczebla BEMIP (Baltic Energy Market Interconnection Plan), której podstawowym celem jest osiągnięcie otwartego i zintegrowanego regionalnego rynku energii elektrycznej i gazu między krajami UE w regionie Morza Bałtyckiego, grupa robocza wysokiego szczebla do spraw połączeń energetycznych w Europie Środkowej i Południowo-Wschodniej (CESEC), grupa robocza wysokiego szczebla do spraw połączeń międzysystemowych dla Europy Południowo-Zachodniej oraz współpraca energetyczna Mórz Północnych (NSEC) łącząca region Morza Północnego.

W sektorze elektroenergetycznym poziom minimalnych połączeń międzysystemowych określono na szczycie Rady Europejskiej w październiku 2014 r. na poziomie $10 \%$ zainstalowanej zdolności wytwarzania energii w państwach członkowskich. Poziom 10\% transgranicznych połączeń elektroenergetycznym państwa członkowskie mają osiągnąć do końca 2020 r. Znaczne postępy w tym zakresie osiągnięto w regionie państw bałtyckich. Ze sprawozdania Komisji [Czwarte sprawozdanie..., 2019] wynika, że poziom połączeń pomiędzy państwami bałtyckimi, które były niegdyś wyspami energetycznymi wynosi $23,7 \%$. Postępy są widoczne także odnośnie wzmocnienia połączeń międzysystemowych z Hiszpanią. Warto w tym miejscu wspomnieć przede wszystkim o INELFE (Interconexión Eléctrica Francia-España or Electricity Interconnection France-Spain) i dwóch kluczowych projektach: połączeniu elektryczne między Baixas - Santa Llogaia ukończonym w 2015 roku oraz podmorskim połączeniu elektroenergetycznym z Francją przez Zatokę Biskajską, które niemal podwoi moc wymiany (z 2800 do 5000MW). Prace nad podmorskim połączeniem rozpoczęły się w 2017 roku a aktualnie są na etapie badań technicznych i środowiskowych.

Do najważniejszych osiągnieć w sektorze gazu należy zaliczyć zaawansowane prace nad ukończeniem Korytarza Północ-Południe w Europie Środkowo-Wschodniej i Południowo-Wschodniej. Korytarz ma połączyć terminal LNG w Świnoujściu jedną nitką ze Słowacją, drugą natomiast z Czechami a następnie przez Węgry z terminalem Croatia na wyspie Krk w Chorwacji. Połączenia międzysystemowe pozwolą na zastosowanie mechanizmu solidarnościowego w przypadku kryzysu.

\section{REALIZACJA CELÓW POLITYKI ENERGETYCZNO- KLIMATYCZNEJ}

Unia energetyczna jest projektem, który ma pomóc w osiągnięciu celów polityki energetyczno- klimatycznej do roku 2030 oraz osiągnięciu neutralności klimatycznej do roku 2050. Są to cele dotyczące efektywności energetycznej, 
udziału odnawialnych źródeł energii w produkcji energii oraz obniżeniu emisyjności gospodarki poprzez redukcję wytwarzania gazów cieplarnianych.

W zakresie trzeciego filaru dzięki wejściu w życie postanowień znowelizowanej w 2018 r. dyrektywy w sprawie efektywności energetycznej [Dyrektywa $2018 / 2002 \ldots, 2018$ ] został podniesiony cel dotyczący poprawy efektywności energetycznej z $27 \%$ do $32,5 \%$ do roku 2030 . Cel ma zostać osiągnięty poprzez dwa priorytetowe działania: zwiększenie efektywności energetycznej w sektorze budownictwa oraz działania na rzecz energooszczędnego i niskoemisyjnego sektora transportu. W sektorze budownictwa przede wszystkim przyjęto w $2018 \mathrm{r}$. dyrektywę w sprawie charakterystyki energetycznej budynków [Dyrektywa 2018/844, 2018], która nakłada na państwa członkowskie obowiązek ustanowienia długoterminowych strategii renowacji. Strategia ma na celu wsparcie procesu renowacji budynków tak, aby do $2050 \mathrm{r}$. stały się budynkami o niemal zerowym zużyciu energii. Zgodnie z postanowieniami dyrektywy od dnia 31.12.2020 r. wszystkie nowe budynki muszą być budynkami o niemal zerowym zużyciu energii. Oznacza to, że zarówno publiczne budynki jak i prywatne muszą spełniać ten wymóg. Natomiast od 31.12.2018 r. wszystkie nowe budynki publiczne są budowane jako budynki o niemal zerowym zużyciu energii. Do dyrektywy Komisja wydała także zalecenia dotyczące renowacji budynków [Zalecenie 2019//786, 2019] i w sprawie modernizacji budynków [Zalecenie 2019/1019, 2019]. Ważne miejsce w sektorze budownictwa odgrywa także ogrzewanie i chłodzenie. W tym miejscu warto wspomnieć o wydanej w 2016 r. przez Komisję „Strategii UE w zakresie ogrzewania i chłodzenia" [Strategia UE w zakresie ogrzewania ..., 2016], w której zainicjowała cykl okrągłych stołów dla przedstawicieli branży w 2018 i 2019 r. w celu omówienia barier w efektywności energetycznej i odnawialnych źródłach energii. Na podstawie danych zebranych podczas okrągłych stołów w 2020 r. Komisja Europejska opracowała raport „Kształtowanie zrównoważonego przemysłu. Wytyczne dotyczące najlepszych praktyk i zaleceń dotyczących polityki”. Skierowany jest on do pięciu najbardziej energochłonnych sektorów, w tym także do budownictwa w zakresie ogrzewania i chłodzenia i zawiera wzorce oraz wytyczne dotyczące najlepszych praktyk w branży.

W sektorze transportu Komisja zaproponowała w Strategii ramowej aby kłaść nacisk na zaostrzenie norm emisji $\mathrm{CO}_{2} \mathrm{w}$ odniesieniu do samochodów osobowych i dostawczych w okresie po 2020 r. oraz na środki mające na celu zwiększenie efektywności paliwowej i zmniejszenie emisji $\mathrm{CO}_{2} \mathrm{w}$ odniesieniu do pojazdów ciężarowych i autobusów. W tym celu zostały wydane dwa rozporządzenia określające normy emisji $\mathrm{CO}_{2}$ dla nowych samochodów osobowych i dla nowych lekkich pojazdów użytkowych oraz określające normy emisji $\mathrm{CO}_{2}$ dla nowych pojazdów ciężkich. Dla samochodów osobowych i lekkich pojazdów użytkowych ustanowiono wymóg aby średni roczny poziom emisji $\mathrm{CO}_{2}$ unijnego parku pojazdów, w porównaniu do 2021 r., został zredukowany o 15\% na lata 2025-2029 oraz o $37,5 \%$ dla nowych samochodów i $31 \%$ dla nowych vanów po roku 2030 . Natomiast w zakresie pojazdów ciężkich ustanowiono cel 15\% redukcji po $2025 \mathrm{r}$. a od 
2030 r. aż 30\% redukcji w odniesieniu do okresu od 1 lipca 2019 r. do 30 czerwca 2020 r. Aby osiągnąć założone cele zwiększenia efektywności w sektorze transportu Komisja będzie promować stosowanie systemów opłat drogowych w oparciu o zasady „zanieczyszczający płaci” i „użytkownik płaci”. W 2017 r. Komisja Europejska przedstawiła w tej sprawie dwa projekty: znowelizowania dyrektywy w sprawie pobierania opłat za użytkowanie niektórych rodzajów infrastruktury przez pojazdy ciężarowe oraz projekt dyrektywy w sprawie interoperacyjności systemów elektronicznego poboru opłat drogowych i ułatwiania transgranicznej wymiany informacji na temat przypadków nieuiszczenia opłat drogowych w Unii. Dyrektywa w sprawie interoperacyjności [Dyrektywa 2019/520,2019] została przyjęta i weszła w życie w kwietniu 2019 r.

Odnośnie działań w sektorze transportu warto wspomnieć o „Europejskiej strategii na rzecz mobilności niskoemisyjnej" [Strategia na rzecz mobilności..., 2016] wydanej przez Komisję w 2016 r. W strategii został określony ambitny cel: do połowy stulecia emisje gazów cieplarnianych z sektora transportu należy zmniejszyć do poziomu niższego o co najmniej 60 proc. w stosunku do poziomu z roku 1990, a następnie dalej konsekwentnie ograniczać aż do poziomu zerowego. Jako działania priorytetowe wymieniono: bardziej efektywny system transportowy; niskoemisyjne, alternatywne źródła energii na potrzeby transportu oraz pojazdy niskoemisyjne i bezemisyjne.

W zakresie filaru czwartego dotyczącego obniżenia emisyjności Komisja zaproponowała działania w dwóch dziedzinach: ambitną politykę przeciwdziałania zmianie klimatu oraz osiągnięcie pozycji lidera w zastosowaniu odnawialnych źródeł energii. Działania te mają doprowadzić do osiągnięcia celu - 40\% redukcji emisji gazów cieplarnianych w porównaniu z rokiem 1990. Warto dodać, że z propozycji Komisji z grudnia 2019 r. zawartej w komunikacie „Europejski Zielony Ład” [Europejski Zielony Ład, 2019] wynika, że cel ten może zostać podniesiony do 50\% lub nawet $55 \%$. Ambitna polityka przeciwdziałania zmianie klimatu prowadzona jest głownie w oparciu o unijny system handlu uprawnieniami do emisji, który został ustanowiony w 2003 r. na mocy dyrektywy [Dyrektywa 2003/87/WE, 2003]. Jednak przepisy w niej zawarte nie były wystarczające do osiągnięcia celów klimatycznych do $2030 \mathrm{r}$. W skutek nadpodaży uprawnień do emisji ceny tychże uprawnień zaczęły spadać co z kolei przestało mobilizować do inwestycji w czyste technologie. Wobec tego Komisja zaproponowała reformę dyrektywy. Nowa dyrektywa [Dyrektywa 2018/410, 2018] ma na celu dalszą redukcję emisji gazów cieplarnianych zgodnie z porozumieniem paryskim z 2015 r. a także usprawnienie systemu oraz wyeliminowanie wad, które wykryto w poprzedniej dyrektywie. Dyrektywa wprowadza dwie zasadnicze kwestie. Po pierwsze od 2021 r. ma być stopniowo zmniejszana liczba uprawnień o $2,2 \%$ rocznie. Po drugie, dyrektywa wprowadza mechanizm Rezerwy Stabilności Rynkowej, który działa już od 2019 r. W momencie, gdy liczba uprawnień w obiegu przekroczy określony poziom zostanie skorygowana do prawidłowej ilości. Zapobiegnie to obniżeniu cen uprawnień. Dyrektywa aby zapobiec ucieczce produkcji do państw trzecich przewiduje udzielenie najbardziej 
narażonym na to sektorom $100 \%$ bezpłatnych uprawnień. W przypadku mniej narażonych sektorów przewiduje się redukcję przydziału bezpłatnych uprawnień po 2026 r. z maksymalnie 30 proc. do 0 na koniec etapu tj. 2030 r.

Drugim obszarem priorytetowym jest osiągnięcie pozycji lidera $\mathrm{w}$ dziedzinie odnawialnych źródeł energii. Najbardziej istotnym aktem prawnym jest dyrektywa wydana w $2018 \mathrm{r}$. w sprawie promowania stosowania energii ze źródel odnawialnych [Dyrektywa 2018/2001, 2018]. Zawarty został w niej cel UE w odniesieniu do udziału OZE w bilansie energetycznym w 2030 r. który ustanowiony został na poziomie $32 \%$ z klauzulą dotyczącą ewentualnej rewizji $\mathrm{w}$ górę do 2023 r. Dyrektywa reguluje także status prosumenta oraz ustanawia wspólne zasady w zakresie stosowania energii odnawialnej w sektorze energii elektrycznej, ogrzewania i chłodzenia oraz transportu w UE. Co istotne, dyrektywa przyspiesza procedury wydawania zezwoleń na budowę projektów - upraszcza procedury, skraca terminy. Ustanawia także mechanizm transferów statystycznych. Dzięki temu państwo, które przekroczyło swoje cele odnośnie udziału OZE w bilansie energetycznym może nadwyżki odsprzedać państwu, które celu nie osiągnęło. W celu ułatwienia transakcji na mocy dyrektywy została ustanowiona unijna platforma do spraw rozwoju odnawialnych źródeł energii (URDP), która będzie miejscem obrotu udziałami OZE po roku 2020 [Wróbel, Brussels, Ścigan, 2020]. W dyrektywie jednak nie zostały sprecyzowane stawki za nadwyżki energii z OZE co może stanowić kwestię problematyczną przyszłych transferów.

\section{BADANIA NAUKOWE, INNOWACJE I KONKURENCYJNOŚĆ}

Ostatnim filarem są działania na rzecz badań naukowych, innowacji i konkurencyjności. W tym miejscu warto wymienić strategię opracowaną przez Komisję Europejską - Europejski strategiczny plan w dziedzinie technologii energetycznych, Plan EPSTE [W kierunku zintegrowanego..., 2015]. Dziesięć kluczowych działań planu EPSTE dotyczy priorytetów badań naukowych i innowacji w unii energetycznej. Realizowany jest w celu przyspieszenia transformacji systemu energetycznego oraz obniżenia kosztów dzięki skoordynowanym działaniom badawczym.

Komisja Europejska wydała także komunikat [Przyspieszenie innowacji..., 2016], w którym przedstawiono strategię UE w zakresie pobudzenia badań naukowych $\mathrm{i}$ innowacji. W strategii wymieniono trzy działania priorytetowe. Pierwszym jest ustanowienie mocnych i spójnych środków zachęty w odniesieniu do inwestycji sektora prywatnego w badania, rozwój i wdrażanie czystych technologii energetycznych. Drugim obszarem jest wdrożenie ukierunkowanych instrumentów finansowych zmniejszających ryzyko obciążające inwestycje sektora prywatnego w niesprawdzone, ale obiecujące czyste technologie energetyczne lub modele biznesowe związane z takimi technologiami. Ostatnim natomiast obszarem jest ukierunkowanie finansowania badań naukowych i innowacji, w szczególności za pośrednictwem programu „Horyzont 2020”, aby poszerzać granice nauki i wiedzy. 


\section{ZAKOŃCZENIE}

Podsumowując, osiągnięcia w ramach tworzenia unii energetycznej należy ocenić w większości pozytywnie. Inwestycje w infrastrukturę przesyłową oraz w terminale LNG realizowane w latach 2015-2020 wzmocniły bezpieczeństwo energetyczne państw członkowskich poprzez zwiększenie dywersyfikacji dostawców i tras dostaw. Szczególne znaczenie ma to bezsprzecznie dla państw, które uzależnione były od jednego dostawcy. W „Czwartym sprawozdaniu” Komisja podaje, że niemal wszystkie państwa członkowskie z wyjątkiem jednego mają już dostęp do dwóch niezależnych źródeł gazu. Dzięki temu, państwa członkowskie są w większym stopniu zabezpieczone przed sytuacjami jakie miały miejsce w 2006 i 2009 roku. Jednak należy zwrócić uwagę także na negatywne działania w zakresie infrastruktury. Przede wszystkim wiele milionów euro zostało wydane na gazociągi które nigdy nie powstały i nie wiadomo czy powstaną. Warto tu przywołać połączenie pomiędzy Hiszpanią a Francją tj. gazociąg Midcat, który został całkowicie anulowany, projekt gazowy Eastring łączący Słowację z granicą bułgarsko-turecką przez Rumunię i Węgry (został wstrzymany na czas nieokreślony) lub gazociąg BRUA.

W zakresie tworzenia rynku energii wzmocniono połączenia międzysystemowe zarówno w sektorze gazu jak i energii elektrycznej jednak wiele jest jeszcze do zrealizowania aby osiągnąć w pełni zintegrowany wewnętrzny rynek energii. Do sukcesów z pewnością należy zaliczyć wprowadzenie nowych regulacji prawnych w ramach czwartego pakietu energetycznego lub tzw. pakietu zimowego. Dzięki temu możliwa jest dalsza integracja w ramach unii energetycznej gdyż kompleksowe ramy prawne stanowią solidną podstawę do skutecznego funkcjonowania wewnętrznego rynku energii. Wyzwaniem w zakresie skutecznego funkcjonowania rynków energii jest przede wszystkim sprostanie nowym realiom rynku coraz bardziej zdominowanemu przez OZE oraz wzajemne połączenia, które poza niezmiernymi zaletami powodują także zagrożenia.

Do sukcesów w zwiększaniu efektywności należy zaliczyć działania podejmowane przez państwa członkowskie w sektorze budownictwa w zakresie renowacji budynków a przede wszystkim termomodernizacji oraz powstawanie budynków, które są niemal zeroenergetyczne. W sektorze transportu warto podkreślić przechodzenie na pojazdy niskoemisyjne oraz promowanie transportu publicznego, w tym pojazdów komunikacji publicznej na silnikach w pełni elektrycznych.

Działania w obszarze filaru czwartego unii energetycznej należy stwierdzić, że prowadzone są intensywnie aby osiągnąć zakładane cele polityki klimatycznej. Warto zaznaczyć, że poza działaniami w obrębie unii energetycznej UE eksportuje swój dorobek i doświadczenia z systemem ETS do państw spoza UE za pośrednictwem dyplomacji klimatycznej. Celem tych działań jest utworzenie kilku systemów handlu emisjami, który ostatecznie połączyłby się w jeden globalny system handlu uprawnieniami do emisji. Prowadzone działania dyplomacji klimatycznej oraz promowanie osiągniecia neutralności klimatycznej zaowocowały 
przyjmowaniem podobnej polityki przez inne państwa na świecie. 26 października 2020 r. Japonia a następnie Korea Południowa zapowiedziały osiągniecie zeroemisyjności w 2050 roku, wskazując na przykład UE. Natomiast inwestycje w OZE w dalszym ciągu są napędzane licznymi dotacjami oraz mechanizmami wsparcia. Jednak warto zauważyć, że zwiększa się ilość inwestycji w OZE, które nie są inicjowane jedynie przez dotacje publiczne a napędzane są potrzebami rynkowymi. Energia odnawialna stała się bardziej przystępna cenowo poprzez obniżenie kosztów technologii oraz zmniejszenie dotacji i może w niedługiej perspektywie konkurować z energią pochodzącą z konwencjonalnych źródeł energii.

Natomiast działania w zakresie badań i innowacji w ramach unii energetycznej opierają się na wyznaczeniu kierunków tychże badań, ustanowieniu strategii, ułatwieniu współpracy między państwami członkowskimi w tym zakresie oraz na wsparciu finansowym projektów w formie dotacji, gwarancji lub pożyczek z budżetu UE w ramach różnych instrumentów finansowych np. Horyzont Europa, LIFE+, Program NER300, Instrument „Łącząc Europę”, COSME, Europejskie Fundusze Strukturalne i Inwestycyjne. Szczególnie udany okazał się instrument InnovFin służący do wspierania projektów demonstracyjnych w dziedzinie energii. W 2018 r. w ramach instrumentu uruchomiono fundusze w kwocie ponad 140 mln EUR.

Uogólniając unia energetyczna osiągnęła częściowe sukcesy w poszczególnych filarach. Jednak warto zwrócić uwagę na rozbieżności w prowadzonej polityce UE a realnymi działaniami. Widoczne jest to chociażby na przykładzie projektu Nord Stram II. Projekt, który jeszcze bardziej uzależnia UE od dostaw z kierunku wschodniego jest dalej realizowany narażając państwa tranzytowe takie jak Polska czy Ukraina na straty finansowe oraz związane z możliwością zastosowania szantażu energetycznego [Tomaszewski 2018]. Sytuacja ta podważa zasadność unii energetycznej, która opierać się ma na solidarności państw członkowskich i stawia pod znakiem zapytania prowadzenie wspólnej unijnej polityki energetycznej mówiącej jednym głosem w ramach unii energetycznej.

Title: Energy Union - concept, implementation and current situation

\begin{abstract}
The aim of the article is to analyze the Energy Union - a project of integration the Member States in the energy sector which was officially announced by the European Comission in 2015. The article analyzes concept of the Energy Union and the progress of realization. The Energy Union project is the first initiative to integrate the Energy sector.
\end{abstract}

Keywords: energy union, energy policy, integration of energy sector, energy and climat policy 


\section{BIBLIOGRAFIA}

1. Jarosiewicz A., Poludniowy Korytarz Gazowy. Azersko-turecki projekt w rozgrywce Rosji i UE, „Punkt Widzenia”, Ośrodek Studiów Wschodnich im. Marka Karpia, Warszawa 2015.

2. Dyrektywa Parlamentu Europejskiego i Rady (UE) 2003/87/WE z dnia 13 października 2003 r. ustanawiająca system handlu przydziałami emisji gazów cieplarnianych we Wspólnocie oraz zmieniająca dyrektywę Rady 96/61/WE, Dz. U UE L 275/32, 25.10.2003.

3. Dyrektywa Parlamentu Europejskiego i Rady (UE) 2018/410 z dnia 14 marca 2018 r. zmieniająca dyrektywę 2003/87/WE w celu wzmocnienia efektywnych pod względem kosztów redukcji emisji oraz inwestycji niskoemisyjnych oraz decyzję (UE) 2015/1814, Dz.U. L 76 z 19.3.2018

4. Dyrektywa Parlamentu Europejskiego i Rady (UE) 2018/844 z dnia 30 maja 2018 r. Zmieniająca dyrektywę 2010/31 / UE w sprawie charakterystyki energetycznej budynków i dyrektywę 2012/27 / UE w sprawie efektywności energetycznej, Dz.U. L 156 z 19.6.2018.

5. Dyrektywa Parlamentu Europejskiego i Rady (UE) 2018/2001 z dnia 11 grudnia 2018 r. w sprawie promowania stosowania energii ze źródeł odnawialnych, Dz. U. UE L 328/82, 21.12.2018.

6. Dyrektywa Parlamentu Europejskiego i Rady (UE) 2018/2002 z dnia 11 grudnia 2018 r. zmieniająca dyrektywę 2012/27/UE w sprawie efektywności energetycznej, Dz. U UE L 328, 21.12.2018

7. Dyrektywa Parlamentu Europejskiego i Rady (UE) 2019/520 z dnia 19 marca 2019 r. w sprawie interoperacyjności systemów elektronicznego poboru opłat drogowych i ułatwiania transgranicznej wymiany informacji na temat przypadków nieuiszczenia opłat drogowych w Unii, Dz.U. L 91 z 29.3.2019.

8. Europejskie Centrum Projektów Pozarządowych Perspektywy rozbudowy Poludniowego Korytarza Gazowego, https://www.ecpp.org.pl/perspektywy-rozbudowy-poludniowego-korytarzagazowego/.

9. Flouri M., KarakostaCh., Kladouchou Ch., Psarras J. (2015), How does a natural gas supply interruption affect the E U gas security? A Monte Carlo simulation, „Renewable and Sustainable Energy Reviews", no. 44.

10. Garrison C. E. (1981), The energy crisis: a process of social definition, „Qualitative Sociology”, vol. 4(4), Human Science Press.

11. Gawlikowska- Fyk A., Zarzadzanie uniq energetyczna - transfer kompetencji do UE, Biuletyn Polskiego Instytutu Spraw Międzynarodowych, Nr 113 (1686), 22 sierpnia 2018.

12. INELFE, The electricity interconnection across the Biscay Gulf, https://www.inelfe.eu/en/ projects/bay-biscay.

13. Juszczuk M., Koncepcja unii energetycznej krajów członkowskich UE jako próba odpowiedzi na potrzeby inwestycyjne $w$ warunkach instytucjonalizacji narzędzi na rzecz rozwoju infrastruktury przesyłowej w sektorze energii elektrycznej, [w:] G. Wojtkowska-Łodej (red), Europejska unia energetyczna. Wybrane zagadnienia, Szkoła Główna Handlowa, Warszawa 2016.

14. Kancelaria Senatu, Przedstawiciel Kancelarii Senatu przy Unii Europejskiej, Inicjatywa Jerzego Buzka i Jacquesa Delorsa ws. Utworzenia Europejskiej Wspólnoty Energetycznej, Sprawozdanie nr 26/2010, Bruksela, 06.05.2010.

15. Komunikat Komisji do Parlamentu Europejskiego, Rady, Europejskiego Komitetu Ekonomiczno - Społecznego, Komitetu Regionów i Europejskiego Banku Inwestycyjnego, Czwarte sprawozdanie na temat stanu unii energetycznej, COM(2019) 175 final, Bruksela, 9.4.2019 r.

16. Komunikat Komisji do Parlamentu Europejskiego, Rady, Europejskiego Komitetu Ekonomiczno - Społecznego, Komitetu Regionów i Europejskiego Banku Inwestycyjnego, Przyspieszenie innowacji w dziedzinie czystej energii, COM(2016) 763 final, Bruksela, 30.11.2016 r. 
17. Komunikat Komisji do Parlamentu Europejskiego, Rady, Europejskiego Komitetu Ekonomiczno-Społecznego, Komitetu Regionów, Europejska strategia na rzecz mobilności niskoemisyjnej, COM/2016/0501 final, Bruksela 20.7.2016 r.

18. Komunikat Komisji do Parlamentu Europejskiego, Rady, Europejskiego Komitetu Ekonomiczno-Społecznego, Komitetu Regionów, Europejski Zielony Ład, COM(2019) 640 final, Bruksela, 11.12.2019.

19. Komunikat Komisji do Parlamentu Europejskiego, Rady, Europejskiego Komitetu Ekonomiczno - Społecznego, Komitetu Regionów, Strategia ramowa na rzecz stabilnej unii energetycznej opartej na przyszłościowej polityce w dziedzinie klimatu, COM(2015) 80 final, Bruksela, dnia 25.2.2015 r.

20. Komunikat Komisji do Parlamentu Europejskiego, Rady, Europejskiego Komitetu Ekonomiczno-Społecznego i Komitetu Regionów, Strategia UE w zakresie ogrzewania i chtodzenia, COM / 2016/051 final, Bruksela 16.2.2016.

21. Komunikat Komisji Europejskiej do Parlamentu Europejskiego, Rady, Europejskiego Komitetu Ekonomiczno-Społecznego i Komitetu Regionów, W kierunku zintegrowanego strategicznego planu $w$ dziedzinie technologii energetycznych (SET) C/2015/6317.

22. Kucharska A., Rola Niemiec w Unii Europejskiej w kontekście budowy unii energetycznej, Sprawy Międzynarodowe 2018, nr 71 (2), s. 189-212.

23. Mapa drogowa na rzecz Unii Energetycznej dla Europy, Non-paper adresujacy wyzwania zależności energetycznej UE, https://www.msz.gov.pl/resource/fc25e49c-a646-4b8a-bc7d5336dac99670:JCR.

24. Misiągiewicz J., Bezpieczeństwo energetyczne Unii Europejskiej. Implikacje nowych projektów infrastruktury gazociagowej w Europie, Wydawnictwo Uniwersytetu Marii Curie-Skłodowskiej, Lublin 2019.

25. Rozporządzenie Parlamentu Europejskiego i Rady (UE) 2017/1938 z dnia 25 października 2017 r. dotyczące środków zapewniających bezpieczeństwo dostaw gazu ziemnego i uchylające rozporządzenie (UE) nr 994/2010, Dz. U. UE L 280, 28.10.2017.

26. Ruszel M., Wpływ Polski na ksztaltowanie polityki energetycznej UE w: J. M. Fiszer, Dziesięć lat członkostwa Polski w Unii Europejskiej. Próba bilansu i nowe podejście, Warszawa 2015.

27. Sprawozdanie Komisji Europejskiej dla Parlamentu Europejskiego, Rady, Europejskiego Komitetu Ekonomiczno- Społecznego, Komitetu Regionów i Europejskiego Banku Inwestycyjnego, Czwarte sprawozdanie na temat stanu unii energetycznej, COM(2019) 175 final, Bruksela, 09.04.2019.

28. Tomaszewski K, Energy solidarity in the European Union in the context of the particular interests of the Member States, „Polityka Energetyczna” 2018 vol. 21.

29. Trubalska J., W kierunku unii energetycznej. Nowa koncepcja bezpieczeństwa energetycznego w Unii Europejskiej, Zeszyty Naukowe Instytutu Gospodarki Surowcami Mineralnymi i Energią Polskiej Akademii Nauk 2017, nr 97, s. 21-32.

30. Wróbel P., Brussels G., Ścigan M., Cel OZE na 2020: co się stanie, jeśli Polska go nie osiagnie?, Forum Energii, https://www.cire.pl/item,195211,13,0,0,0,0,0,cel-oze-na-2020-co-sie-staniejesli-polska-go-nie-osiagnie.html.

31. Zalecenie Komisji (UE) 2019/786 z dnia 8 maja 2019 r. w sprawie renowacji budynków (notyfikowana jako dokument nr C(2019) 3352), Dz.U. L 127 z 16.5.2019.

32. Zalecenie Komisji (UE) 2019/1019 z dnia 7 czerwca 2019 r. W sprawie modernizacji budynków, Dz.U. L 165 z 21.6.2019. 